\title{
21 My path to a theology of Qi
}

\author{
Hyo-Dong Lee
}

The Theology Without Walls (hereafter TWW), as I understand it, is "a theology without confessional restrictions." ${ }^{11}$ It is a theology in a mode of transreligious inquiry that engages the resources of multiple traditions without prioritizing any single one among them. As such, it is a more experimental and perhaps daring form of theology, given the widely accepted customary definition of theology as "the articulation of religious truths as held by a particular tradition" (Martin 2016). Further, precisely as such it diverges from comparative theology, which Francis X. Clooney defines as consisting in "acts of faith seeking understanding which are rooted in a particular faith tradition but which, from that foundation, venture into learning from one or more other faith traditions" (Clooney 2010, 10). The prevailing understanding of comparative theology - as championed by Clooney and Paul Knitter, among others - assumes one's rootedness in a single home tradition from which one undertakes the adventure of passing over to other traditions and coming back with a deeper understanding of the home tradition. TWW is premised on more complicated patterns of religious affiliation (or nonaffiliation), which do not presume one's rootedness in a single home tradition. Whether affiliation is envisaged as belonging in the sense of membership in particular religious communities or as participation in certain religious practices, the practitioners of TWW in principle do not give more authority and weight to one tradition over others with which they affiliate themselves (Thatamanil 2016b, 355). ${ }^{2}$ Hence, the issue of multiple religious belonging or multiple religious participation accompanies the theoretical endeavor of TWW as its existential and practical horizon.

As a Christian comparative theologian who grew up in East Asia (South Korea), I have found the underlying premise of comparative theology, that is, that the comparative theologian is rooted in a single home tradition, most challenging to make sense of. I was born into a family without membership in an organized religion but committed to Confucian ritual and ethical obligations, particularly the ritual of ancestor veneration. The religious landscape was characterized by what is called "diffuse religion" - the ancient practices of ancestor veneration and spirit worship that over time became amalgamated with basic elements of Buddhism, Confucianism, and Seondo 
(a Korean form of Daoism), in which it was common for an individual or family to participate in religious rituals or practices that suited the occasion (Esposito, Fasching, and Lewis 2012, 495). Before Christianity arrived on the scene, "religions" in the sense of organized communities with exclusive membership did not really exist. Although different people might be respectively more committed overall to the practices of one tradition over the others, in most cases they treated one another with respect and in that sense can be said to have accepted a loose concept of multiple religious belonging (Kim 2016, 79). Regarding the sense of religious identity and religious ethos in such a context, Chung Hyun Kyung put it best:

When people ask what I am religiously, I say, "My bowel is Shamanist. My heart is Buddhist. My right brain, which defines my mood, is Confucian and Taoist. My left brain, which defines my public language, is Protestant Christian, and overall, my aura is eco-feminist." ... As a Korean woman, I was raised in the 5,000-year-old Shamanist tradition and the 2,000-year-old Taoist-Confucian tradition, with 2,000 years of Buddhist tradition, 100 years of Protestant tradition, and twenty years of eco-feminist tradition. So, my body is like a religious pantheon. I am living with communities of Gods, a continuum of divinity, and a family of religions.

(Kyung 2009, 73-74)

The fact that I was baptized a Christian - more specifically, an evangelical Protestant - in a cultural-religious milieu of "diffuse religion" that assumed a loose sense of multiple religious belonging complicated my relationship to the other traditions. The evangelical Protestant church of which I became a member at the age of 16 demanded an exclusive allegiance to it - I was supposed to regard Christianity as my only "home" and the rest of the religious landscape as consisting in "others." But that was an impossible demand, for however much I formally repudiated Confucianism, Buddhism, etc., as "pagan" and "heathen," I could not disown or erase the childhood and teenage-year memories of taking part in the house rituals of venerating my grandfathers and grandmothers or accompanying my relatives in fun-filled Sunday picnics to nearby Buddhist temples where the sound of the monks' chanting was a soothing music to my ears. Those memories formed an indelible part of who I was as a person; and one could even argue that, in the language of comparative theology, by being baptized a Christian, I was actually leaving "home" to embark on the adventurous journey of crossing-over into a "foreign" tradition. ${ }^{3}$

Such a complex pattern of religious affiliation perhaps explains the sense of ease and safety with which I explored Confucian and Daoist philosophies in my college years in South Korea, despite my formal consent to the doctrinal stance of my church that declared them to be error-filled human creations, if not the work of the devil. I was especially attracted to the teachings 
of the Daodejing (or Laozi), the earliest and foundational scripture of Daoism, although at the time I had no intellectual frame or tools to reconcile, if possible at all, its teachings of Dao, "self-so" (自然 ziran) and "nonself-assertive action” (無爲 wuwei) with my church's thoroughly Western, missionary-brought theology. I started studying the Daodejing in earnest during my graduate studies of theology in Canada and the United States, when I was preoccupied with the question of how to reduce the distance I felt existed between the glorified Trinity and the fallen creation in much of classical Christian theology.

My theological quest then had a decisively pneumatocentric orientation, having been influenced by Rahner's dictum, "the immanent Trinity is the economic Trinity and vice versa"; Moltmann's revamping of Barth's trinitarian history of God as virtually coinciding with the history of creation's redemption, emancipation, and healing; and ultimately, Hegel's grand vision of the consummation of the absolute in the divine-human-cosmic unity of the Geist, Spirit. It was an attempt to reconceive God's transcendence - or God's own being, traditionally captured by the notion of the "immanent" Trinity - so as to find it right in the midst of, not apart from, the common history of God and creation. ${ }^{4}$ Following Hegel, I wanted to re-envision God's ultimate being as Spirit, understood as the all-encompassing divinehuman-cosmic unity, which unceasingly worked at the liberation and ultimate consummation of itself. ${ }^{5}$

With its paradoxical conception of the Dao (Way) as both the unnamable Dao and the Mother of the world, the Daodejing offered me a resonant account that located the ultimate squarely at the heart of a divine-humancosmic whole, while retaining a sense of the Dao's ultimate transcendence of that whole as a kind of natura naturans. ${ }^{6}$ Moreover, the Daodejing presented a vision of the pre-civilizational undercurrent of nature beneath the human world as most perfectly aligned with the movement of the Dao. In other words, it proffered a counterthrust to Hegel's anthropocentrism and Eurocentrism, that is, his prioritizing of human culture, especially in its modern European Enlightenment version, as the most privileged locus of divine-cosmic reconciliation.

The fact that I turned to classical Daoist thought to find intellectual resources for the task had certainly a lot to do with the familiarity and comfort with which the ancient Daoist texts spoke to me, as if I was hearing my own voice. At the same time, it was also due to the dawning awareness on my part that Christian theology had never had its "own" intellectual frameworks and conceptual tools that enabled it to safeguard its orthodoxy. From its very beginning, Christianity in its theoretical self-articulation relied on the intellectual resources of classical Greek and Hellenistic thought, and in that sense had always harbored "others" within itself that rendered the boundaries of its self-identity permeable. If one is to apply the previously mentioned logic of comparative theology for a Christian convert whose home coincides with a "mission field," what happened to Christian theology 
early on was as much the Greek-speaking gentiles leaving their home base to cross over into a foreign Jewish tradition and returning, having been transformed in the process, as Christianity leaving its Jewish home to pass over into the alien world of Greek thought and coming back changed. This bidirectional logic of comparative theology indicates that if there is to be double religious belonging as a version of multiple religious belonging, such a belonging should be understood as symmetrical, not asymmetrical. ${ }^{7}$ Further, it also implies that the long-running debate in ecumenism and missiology about contextualization of theology should expand its understanding of the "inculturation" of theology to include the so-called "grafting" model, according to which the Christian gospel is the shoot (guest) and the local culture the stock (host) onto which the gospel is grafted. ${ }^{8}$

After my first comparative (Christian-Daoist or Daoist-Christian) theological project culminated in a $\mathrm{PhD}$ dissertation on Hegel and the Daodejing, my attention turned to the resources of Confucianism, particularly allured by the conceptual rigor and the grandeur of the vision of NeoConfucian metaphysics. What drew my attention to it was the way the most historically influential school of Neo-Confucian metaphysics, ${ }^{9}$ following its founder Zhu Xi, dynamically structures all of reality in terms of the relationship between psychophysical energy (氣 qi) and pattern (理 $l i$ ). Psychophysical energy is the primordial energy of the universe that constitutes whatever exists, whereas pattern is the ultimate ideal principle of coherence and order which is logically, ontologically, and normatively prior to psychophysical energy and upon which the cosmic creativity of the latter is dependent. In other words, the dominant school of Neo-Confucian metaphysics places the very energy and "stuff" of the universe within an ontologically hierarchical, binary relationship with its raison d'être, its ground of being, its suoyiran (所以然). At the same time, in contrast to the substantialistic portrayals of the metaphysical ultimate as unchanging divine substance found in the dominant strains of classical Western theism and the Indic tradition, the Neo-Confucian metaphysics treats $l i$ as a dynamic ontological creativity that is, as an incessant activity of patterning, structuring, and harmonizing at the very root of the cosmos. ${ }^{10}$

Given my continued theological quest to find a better intellectual framework to articulate God's transcendence as God's deepest immanence in creation, I was attracted to the subtle manner in which the Neo-Confucian metaphysics positioned the metaphysical ultimate $-l i-$ as a dynamic and creative "force" at the root of the universe itself. At the same time, I was both intrigued and flummoxed by the somewhat incongruous idea of the ultimate ideal principle of coherence and order - a kind of lure, guideline, or in some instances, schematic - seemingly functioning as the "agent" of ontological creation. Shouldn't $l i$ as dynamic ontological creativity be construed also as a kind of energy rather than strictly as an ideal principle if it is to serve as the "cause" of ontological causation in the least restrictive sense of the term? This ambiguity in the overarching metaphysical architectonic 
of the dominant Neo-Confucian position drew my attention to the Korean philosophy of $q i$, represented by Yulgok and Nongmun, a sixteenth- and an eighteenth-century Neo-Confucian figure, respectively. What arrested my interest was their move outside the orbit of the "orthodox" school of Zhu $\mathrm{Xi}$ that interpreted $q i$ quasi-dualistically as the dynamic material principle subordinate to $l i$. Especially in Nongmun's conception of it, qi can be said to designate none other than ultimate reality itself, because it has two modes: 1) the cosmic energy that coalesces to become the material and ideal "stuff" of every concrete entity and 2) the original qi that permeates the world of concrete entities to make them creative and living by providing them with a fundamental inclination toward order and value (which is the source of novelty in the universe). This "layering" of $q i$ provides a sense of ontological depth and radically immanent transcendence to the primordial energy of the universe. For Nongmun, $l i$ is merely a name for the original $q i$ to designate specifically the latter's ordering and governing of creative processes. ${ }^{11}$

Yulgok and Nongmun's philosophy of $q i$ suggested to me a way to envision the ultimate as a kind of natura naturans like the Daodejing did, but with a more conceptually robust articulation of the relationship between its world-immanence and world-transcendence. I was inspired to articulate my theological thesis, that the trinitarian God is first and foremost Spirit, as meaning that God is first and foremost the primordial Energy of the universe, without simultaneously being forced to make a distinction between God's unknowable essence (ousia) and God's experienced energy (energeia) like some Eastern Orthodox theologians had done - in order to safeguard divine independence and freedom from creation. ${ }^{12}$ This theological development spurred my transition from a chiefly Hegelian standpoint to one that incorporated insights from Whiteheadian and Deleuzean thoughts. My view of God as some kind of primordial yet all-pervasive creative energy resonated with Whitehead's definition of the ultimate metaphysical ground as the very cosmic process of creative advance into novelty, on the one hand, and Deleuze's notion of chaosmos (i.e., the orders of the universe "bubbling up" from the chaotic background of virtuality), on the other. Catherine Keller's work of creatively blending the two intellectual giants also gently nudged this God as the primordial Energy into the heterogeneous beginning and tehomic depth of the universe and in so doing enabled me to complete the identification of divine radical transcendence with divine radical immanence. ${ }^{13}$

I cannot end this chapter without mentioning Donghak, or Eastern Learning (today called Choendogyo). Donghak is another "home" tradition of mine whose intellectual resources inspired and enriched my theological journey. Donghak is the first indigenous organized religion of Korea born of the crucible of late nineteenth-century Korea in which the traditional teachings of Confucianism, Buddhism, Seondo, and shamanistic folk religion clashed and wrestled with the new arrival, namely, Christianity or Western Learning. The Donghak understanding of ultimate 
reality has two poles. The ultimate is first jigi, or Ultimate Energy (that is, Ultimate Qi). At the same time, Ultimate Energy is a personal deity called haneullim (Lord Heaven), who is both within and outside the human self, identified with the human heart-mind yet coming to meet it from outside as the larger cosmic heart-mind to which the individual heart-mind is called to be attuned. The experience of the personal encounter with Ultimate Qi as Lord Heaven makes one a "bearer of Lord Heaven" who has become one with the rest of the universe and whose entire psychophysical being shares in the cosmic creative-transformative agency of Ultimate Energy. By conferring a clear sense of divine subject agency to the spontaneous and pluriform creativity of the cosmic $q i$ whose harmonizing power is not predicated on some kind of transcendent metaphysical unity, Donghak developed a view of the divine that is both one and many, divine and creaturely, and impersonal and personal. At the same time, as a social movement it worked toward the creation of a free, egalitarian, and inclusive society of "the bearers of Lord Heaven," eventually culminating in the first attempt at democratic revolution in Korean history in the late nineteenth century. ${ }^{14}$

Donghak teachings have helped me overcome a major obstacle in constructing a theology of Spirit while drawing on my East Asian religious and intellectual heritages - that is, the fact that, largely speaking, Confucianism and Daoism are philosophically nontheistic. The polar conception of the ultimate as both Ultimate Energy and Lord Heaven has enabled me to think of God as Spiritual Energy - that is, both the energy of my existence and the object of my prayer and worship. If the spirits of my ancestors who responded to my family's invitation to take a seat at the altar of ancestor veneration to bless us consisted of the same qi of which I was also made, God as Spiritual Energy also responds to my call for help from the chaotic depth of my being and provides succor by "energizing" my $q i$, that is, by strengthening my sinews and bones and stirring in my mind and heart visions of liberation and healing.

Furthermore, Donghak is an East Asian theological source that, however compromised and diluted by sociopolitically dominant traditions, still represents the voice "from the underside of history." Hence, my engagement of it answers the liberationist impulses that have always been present in my theological quest, while helping me respond to the demand of the new generation of comparative theologians that we attune ourselves more to the marginalized voices within the major religious traditions or "outsiders within." ${ }^{15}$ Donghak's ecological and political ideas, as the product of what may be called subversive subaltern reinterpretations of the historically dominant Neo-Confucian ideas, practices, and institutions, have provided suggestive pointers for developing my pneumatocentric reconstruction of the doctrine of the Trinity into a full-blown ecopolitical theology - one that is attuned to the cries of the oppressed, exploited, and marginalized, both human and nonhuman. 
As I mentioned earlier, I have come to reject the universal applicability of the idea of asymmetric belonging so as to allow for a bidirectional conception of the operational logic of comparative theology. Does this mean that I have come to embrace TWW in earnest insofar as it eschews the idea of the primary religion to which one belongs? Perhaps. Yet if the account I have presented here of my path to a theology of $q i$ is any indication, my theologian self does not escape being encumbered and propelled forward by the weight of the historical layers of traditions accumulated and embedded in my body. This explains why, although a chance glance at Augustine's City of God or Nongmun's Miscellaneous Writings from the Deer Hut can get my theological mind and heart all worked up and beating, it is only with an intentional effort that I pick up Sankara's Brahma Sutra Bhasya to receive a fresh insight about God. Hence, the version of TWW that I can accept is one that allows room for a theological thinking spontaneously - and even confessionally - tethered to, but not arbitrarily restricted by, a certain number of concrete teachings and practices as a result of one's existential and historical embeddedness in particular traditions. Such a TWW would raise no objection if I renamed my chapter My Path to a Confucian-DaoistDonghak-Christian Theology of Q $i$, except for the unwieldly nature of the new title.

\section{Notes}

1 This phrase was taken from Jerry Martin's initial proposal for this volume. He articulates the definition and ethos of transreligious theology more fully in his programmatic statement to a section of Open Theology dedicated to the topic (Martin 2016).

2 Whether religious affiliation is to be understood as (identity-shaping) belonging in the sense of membership in religious communities or as participation in certain religious practices is an important distinction drawn by John Thatamanil (Thatamanil 2016a, 9-15).

3 I put the word in quotation marks because Christianity was already a wellestablished part of the religious landscape of Korea, though with a much shorter history and, most importantly, an intellectual - theological - foreignness.

4 Peter Hodgson has very helpfully coined the term "pre-worldly Trinity" for the immanent Trinity and "worldly Trinity" for the economic Trinity to clarify the distinction between the two (Hodgson 1994, 151).

5 For this I am deeply indebted to Peter Hodgson's Hegelian interpretation of the Trinity. See his Winds of the Spirit (Hodgson 1994, 151-172).

6 I am referring to the famous distinction made by Spinoza between natura naturans (nature naturing or active nature) and natura naturata (nature natured or passive nature). Natura naturans is nature taken as the free cause of itself - that is, as God - whereas natura naturata is the same nature seen as contingent, dependent on, and existing in God. (Spinoza 1993, 25). In the Daoist interpretation suggested here, the unnamable Dao as natura naturans implies that natura naturans transcends any unity or order, including the divine-human-cosmic whole (natura naturata) to which it has given birth.

7 According to Heup Young Kim, the notion of asymmetrical belonging advanced by Catherine Cornille, which makes a distinction between the primary religion 
to which one belongs and others with which one identifies, is suspected of harboring the religious, cultural, and philosophical imperialism of the West, especially if the primary religion happens to be Christianity $\operatorname{Kim}(2016,82)$.

8 The "grafting model" is suggested by Kyoung Jae Kim in his Christianity and the Encounter of Asian Religions: Method of Correlation, Fusion of Horizons and Paradigm Shifts in the Korean Grafting Process (1994, 135-141). Here Kim is relying on the ideas of Ryu Dong-sik, one of the pioneers of Korean tochakhwa theology. In the "grafting" model both the Christian tradition and the local function as theological subjects taking part in the creative process of theological indigenization or inculturation.

9 I am here referring to the "orthodox" lineage of the so-called Cheng-Zhu School, whose founding figure is Zhu Xi (朱喜 1130-1200 CE) of the Chinese Southern Song Dynasty.

10 I have presented this account more fully in my book, Spirit, Qi, and the Multitude: A Comparative Theology for the Democracy of Creation (Lee 2014, 62-82).

11 For a fuller account see Spirit, Qi, and the Multitude (Lee 2014, 142-173).

12 For the Eastern Orthodox distinction between divine essence and divine energy, especially that of Gregory Palamos, see Lossky (1974, 52-56). Mary-Jane Rubenstein convincingly argues that the distinction ultimately collapses, because of the intrinsically self-revelatory - that is, relational - nature of divine life (Rubenstein 2011, 38-41).

13 See Spirit, Qi, and the Multitude (Lee 2014, 174-210).

14 See Spirit, Qi, and the Multitude (Lee 2014, 211-243).

15 See Roberts (2010) and Tiemeier (2010).

\section{References}

Clooney, Francis X. 2010. Comparative Theology: Deep Learning Across Religious Borders. Malden, MA: Wiley-Blackwell. doi:10.1002/9781444318951

Esposito, John L., Darrell J. Fasching, and Todd T. Lewis, eds. 2012. World Religions Today. 4th ed. Oxford and New York: Oxford University Press. doi:10.3366/ swc.2007.13.3.301

Hodgson, Peter C. 1994. Winds of the Spirit: A Constructive Christian Theology. Louisville, KY: Westminster John Knox Press. doi:10.1177/004057369605300314

Kim, Heup Y. 2016. "Multiple Religious Belonging as Hospitality: A Korean Confucian-Christian Perspective.” In Many Yet One? Multiple Religious Belonging, edited by Peniel Jusudason Rufus Rajkumar and Joseph Prabhakar Dayam, 75-88. Geneva: World Council of Churches Publications.

Kim, Kyoung J. 1994. Christianity and the Encounter of Asian Religions: Method of Correlation, Fusion of Horizons, and Paradigm Shifts in the Korean Grafting Process. Zoetermeer: Uitgeverij Boekencentrum. doi:10.1163/157254395x00072

Kyung, Chung H. 2009. "Seeking the Religious Roots of Pluralism." In Christian Approaches to Other Faiths: A Reader, edited by Paul Hedges and Alan Race. 73-74. London: SCM Press. doi:10.1111/j.1467-9809.2011.01112.x

Lee, Hyo-Dong. 2014. Spirit, Qi, and the Multitude: A Comparative Theology for the Democracy of Creation. New York: Fordham University Press.

Lossky, Vladimir. 1974. In the Image and Likeness of God, edited by John H. Erickson and Thomas E. Bird. 52-56. Crestwood, NY: St. Vladimir's Seminary Press. doi:10.1017/s0034412500009094

Martin, Jerry L. 2016. “Is Transreligious Theology Possible?” Open Theology 2 (1): 261. doi:10.1515/opth-2016-0021 
Roberts, Michelle V. 2010. "Gendering Comparative Theology." In The New Comparative Theology: Voices from the Younger Generation, edited by Francis X. Clooney. 109-128. New York: Continuum.

Rubenstein, Mary-Jane. 2011. "The Fire Each Time: Dark Energy and the Breath of Creation." In Cosmology, Ecology, and the Energy of God, edited by Donna Bowman and Clayton Crockett. 38-41. New York: Fordham University Press. doi:10.5422/fordham/9780823238958.003.0003

Spinoza, Baruch. 1993. Ethics and Treatise on the Correction of the Intellect, trans. Andrew Boyle. London: J. M. Dent Orion Publishing Group and Rutland, Vermont: Charles E. Tuttle.

Thatamanil, John J. 2016a. "Eucharist Upstairs, Yoga Downstairs: On Multiple Religious Participation.” In Many Yet One? Multiple Religious Belonging, edited by Peniel Jesudason Rufus Rajkumar and Joseph Prabhakar Dayam, 9-15. Geneva: World Council of Churches Publications.

Thatamanil, John J. 2016b. "Transreligious Theology as the Quest for Interreligious Wisdom.” Open Theology 2 (1): 355. doi:10.1515/opth-2016-0029

Tiemeier, Tracy S. 2010. "Comparative Theology as a Theology of Liberation." In The New Comparative Theology: Interreligious Insights from the Next Generation, edited by Francis X. Clooney. London and New York: T \& T Clark. doi:10.1111/j.1467-9418.2012.01050.x 